\title{
The contradictory CAP regulations within the recent, extraordinary transformation of Italian agricultural Systems
}

\author{
Pierluigi De Felice, Maria Gemma Grillotti Di Giacomo
}

\begin{abstract}
Over the past two decades Italian agricultural systems have recorded an extraordinary change in their structural foundations partially due also to the contradictory CAP regulations. The most significant factors that have produced the accelerated evolution in our countryside are two: on the one hand, the recognition and acquisition by the primary sector of new economic, social, environmental and cultural functions, on the other hand, the renewed interest in the beauty of rural areas, the importance of technical sustainable agricultural production and the quality of the food supply sources. To all these aspects, researchers and the general public attribute today the fundamental role of guarantors for the quality of life and human health, animal health and environmental protection. It is a new awareness that, breaking the traditional delay with which the primary sector responds to the cultural activities, with unexpected timing, has translated into concrete, conspicuous forms of land corporate reorganization. Applying the qualitative and quantitative methodology of the Interuniversity Research Group GECOAGRI LANDITALY to the latest census data of the agriculture in 2010, the contribution considers the recent evolution of Italian agricultural systems to evidence landscape outcomes and territorial issues.
\end{abstract}

Received: 04/12/2017, Accepted: 27/01/2018; Published: 30/3/2018

Pierluigi De Felice, Maria Gemma Grillotti Di Giacomo, Università Campus Bio-Medico Roma

Email: p.defelice@unicampus.it

* The authors shared entirely the content of this article, however, with the exclusive scope of evaluating it, it is clarified that paragraphs 1 and 4 are to be attributed to both, while paragraph 2 is to be attributed to Grillotti Di Giacomo, and paragraph 3 to De Felice. The English version was translated by Flaminia Ortenzi.

${ }^{1}$ It was established with the Treaties of Rome which were signed on 15th March 1957, together with the European Economic Community (EEC) and the European Atomic Energy Community (Euratom). Since the very beginning (articles 38-47 of the EEC Treaty) CAP has recognised the fundamental role of the primary sector regarding common policies for development and cohesion, that is to say to carry out those very programmes that are currently requested in
Keywords-regional agricultural systems, Common Agricultural Policy, GECOAGRI LANDITALY methodology

\section{THE ROLE OF CAP IN THE ORGANIZATION OF ITALIAN RURAL AREAS. A BRIEF INTRODUCTION}

The impact that the application of $\mathrm{CAP}^{2}$ regulations has had on the organization of European rural areas is significantly evidenced by the extraordinary and accelerated transformation of Italian agricultural systems. In fact, our country represents a poster study model and an extraordinary laboratory for the variety of the territory and of the natural environments, on which the change was recorded, and for the peculiarity and beauty of historical rural areas where it had an impact. Notwithstanding the EU incentives were progressively directed towards the regionalization of interventions (as shown below in paragraph 2), the enhancement of rural landscapes and the protection of quality agrifood products, the evolution of Italian agricultural systems (paragraph 3) has in fact registered a general concentration of land ownership and growth of industrial crops. Such processes can only be interpreted in light of the CAP contradictory regulations: the incentives granted have too often been absorbed by agro-industrial systems of North-Atlantic Europe in spite of the often declared intention that they were meant to support family farmers and Mediterranean countries' regions whose development lagged behind. The real rebirth of the primary sector appeared to be "en route" only with the

order to face anti-European movements that are present in several countries of the European Union and that were tragically embodied in the referendum results of 23rd June 2016 which established BREXIT, that is the United Kingdom's exit from the European Union. 
introduction of the "single payment per company", therefore independently from the size of the production units and subject to the adoption of "virtuous" agricultural practices. This is the "last agricultural revolution" by which it is possible to understand the accelerated land ownership dynamism and the extraordinary transformation of Italian agricultural systems; a revolution that on the other hand appears to be mortgaged by the incentives to increase biomass production through expansion of non-food cultures (Climate-Energy Package "20-20-20").

\section{REGIONAL AGRICULTURAL SYSTEMS CHANGE SEEN FROM THE TRANSITION OF CAP FROM COMPETITIVENESS TO SUSTAINABLE PRODUCTION}

In the current phase of reconsideration and redefinition of the commitments and of the very ideals that led to the creation of the European Union, the Common Agricultural Policy (CAP) has a fundamental role. Back then CAP already had the following fundamental goals: ensuring fair standards of living for rural people; stabilising markets and prices in favour of farmers; ensuring the safety of food supplies; ensuring reasonable prices of agricultural products in favour of consumers. During its sixty years of life, other aims of environmental and socio-ethical nature have been added to the initial goals that, with the beginning of the Third Millennium, have shifted interests and incentives, previously focused only on increasing agricultural production through technical advancements and competitiveness of enterprises, toward more complex programmes. Such programmes include regionalization of interventions; promotion of the rural landscape; and protection of quality agrifood products [1].

The transition has progressively marked a shift for the European Union from the model of productive agricultural policy, that was founded on quantity and income growth of the outcomes of the primary sector, toward a territorial model which enhances the multifunctional aspects of quality agriculture, as pivotal and main actor in the project of sustainable, integrated regional development, with the capacity to involve other economic sectors (crafts, tourism, trade, services) and all social aspects (values, traditions, ethics, aesthetics).
Based on its various evolution phases, the conversion of CAP from the model of sectoral development to that of territorial development has rolled out over at least six programmatic stages ${ }^{2}$. While each phase deserves a careful analysis, in this context, we will only comment on few which are clear exemplifications to recognize and illustrate the fundamental role that incentives to the primary sector have and continue to play in determining the dynamism of regional agricultural systems and favour or discourage European policies.

The impact that policies sustaining agricultural production growth have had on the territory is far from painless, not only for the natural environment, but also and mostly for the organization of the rural areas and for the livelihoods of local communities, putting regions with slower economic development at a disadvantage. The concept that an economically vital enterprise should not be below 20 ha in dimensions - minimum level set by CAP to access funds - without discouraging the rational use of modern agricultural mechanization and preventing it from falling off the market system, caused that almost the entirety of incentives has been funnelled on large profit enterprises, promoting most suitable yearly monocultures, use of chemical and mechanical means, cost reductions and growth of income rendered per ha of cultivated land. Such a production model is certainly more adequate for North-Atlantic European farms, than those of the Mediterranean basin where the prevailing family farming, less aggressive and specialized, has always remained in the domain of small-medium productive units.

\footnotetext{
${ }^{2}$ The six programmatic phases are: 1) support to growth of production and income rendered by unit ('60s); 2) support to prices and launch of structural policies ('70s and ' $80 \mathrm{~s}) ; 3$ ) setaside policy and enhancement of structural funds devoted to comprehensive territorial development (IMPs -Integrated Mediterranean Programmes- ; LEADER I Programme 1991199 and LEADER II Programme 1994-1999 -Liaisons entre actions de développement de l'économie rurale- ; and rural development Plans) ('90s); 4) policies for comprehensive territorial development and promotion of multifunctional aspects of sustainable agriculture (LEADER + Programme; "Agenda 2000"); 5) regionalization of support interventions and introduction of the "cash bonus per enterprise", delinked from the production activity and subject to the adoption of "value" agricultural practices, mindful of the environment, farmers, consumers, and livestock (Fischler Reform, June 2003); 6) reduction of direct incentives and support to greening and food safety interventions (Reform 2014-2020).
} 
Keeping in mind that in the ' 60 s and ' 70 s only larger enterprises could access CAP funds, and that they factually absorbed the majority of the funds allocated to reach the objectives programmed (growth of income rendered by unit and of total production), it is easily noticeable that the majority of rural areas of the Mediterranean basin countries - generally characterized by agricultural systems with prevalence of micro, small and medium-sized enterprises-would have been, and de facto was, excluded from accessing the incentives (figure 1).

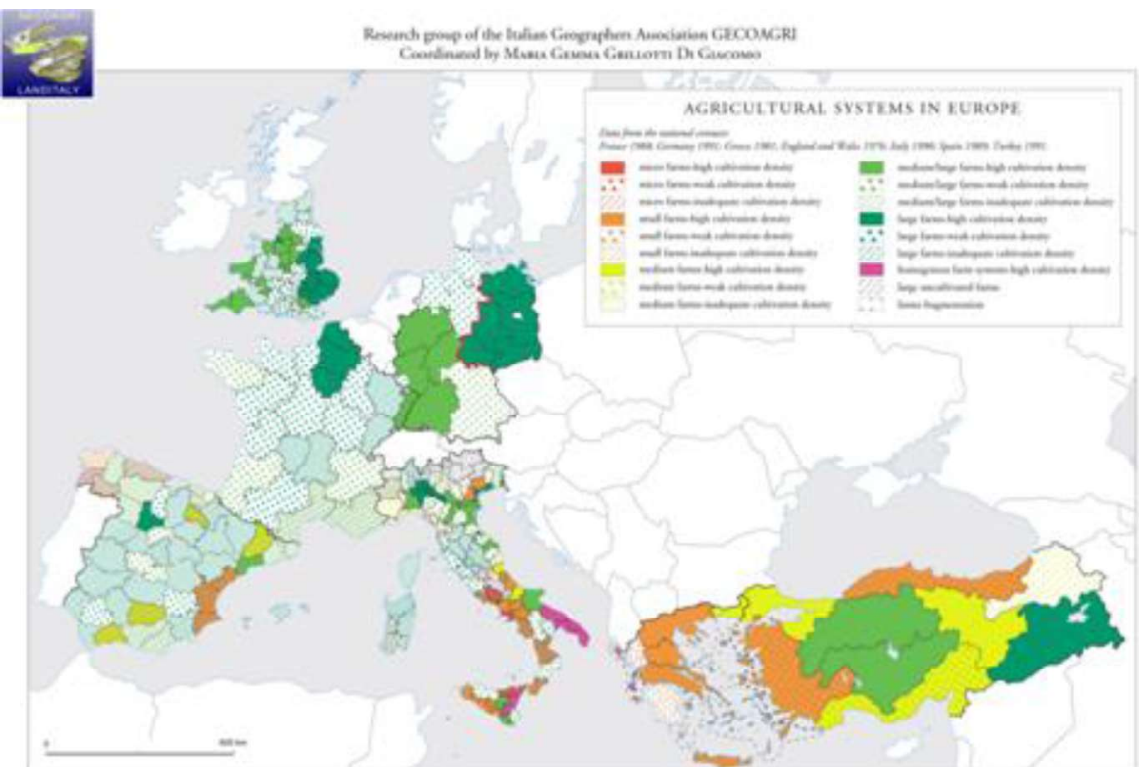

Figure 1. The agricultural systems of European countries: in green those characterized by the prevalence of large enterprises and in red/orange those characterized by the prevalence of micro-small enterprises.

Source: Grillotti Di Giacomo, p. 404 [2].

The exclusion from incentives of Southern Italy and many other Mediterranean Europe regions was aggravated by the adoption of the policy to support prices, which was mainly used by the most competitive agricultural units, that had the capacity to obtain larger quantities of "products to be supported", and that not with standing the start of some weak structural policies in favour of weaker areas, for which only a bare $5 \%$ of CAP funds was reserved. Still in the ' $90 \mathrm{~s}$, during the transition of the agricultural policies from the sectoral model to the territorial model the European Union approved, together with the support of IMPs and LEADER Programmes, the scandalous set-aside policy - a reform proposed by the Irish Mac Sharry - thanks to which, with the aim to rebuild the properties of soils that suffered desertification from excessive exploiting, funds are released in proportion to the quantity of uncultivated land. Once again, the European regions having large enterprises, with vast areas of land to be left uncultivated, were more favoured, thus getting to the point that farmers with more land available are favoured in accessing European funds simply by leaving land uncultivated.

The real turning point in the European Union agricultural policies develops only at the beginning of the Third Millennium, when finally, both the objectives and the strategies to achieve them change. The attention to the protection of the natural resource base is translated into the sustainability of techniques and production phases; and the need to rebuild a healthier balance between agriculture and environment leads to the reconsideration of the value of small-medium farms, where a large part of quality production of the agrifood sector takes place. It is thus clear that the extensive presence on the territory of dynamic and innovative agricultural producers, regardless of the size and economic competitiveness of their enterprises, is in itself sufficient to ensure the indispensable propulsive function for local development and for the protection of biodiversity 
and of the quality of agrifood production ${ }^{3}$ [3].

In June 2003, the mid-term review of CAP, known as Fischler Reform, introduces therefore for the first time the regionalization of support interventions and the "cash bonus per enterprise", delinked from the size of the productive units and subject to the adoption of "value" agricultural practices, mindful of the environment, farmers, consumers, and livestock. A real agricultural revolution that finally makes EU funds accessible and useable by all productive units and consequently also for farmers of the Mediterranean basin and for regions with development lagging behind, where agriculture continues to remain family farming and therefore largely in the hands of small-sized enterprises [4].

The impact of the new European agricultural policies on the Italian agrifood sector is extraordinary. The concern that many agrarian economists had raised following the adoption of the Fischler Reform, namely that the real estate market for agricultural land would have suffered a dramatic halt because it would be more convenient even for the smallest actors to access EU funds, in the decade following the implementation of the 2003 reform turned out to be completely unfounded, as evidenced on the one hand, by the extraordinary dynamism of business structures, previously characterized by a high viscosity (see para. 2), and on the other hand, by the renewed vitality of agricultural entrepreneurship, which witnesses a boost of promotional initiatives for local products (and related requests for trademark registrations) and associated tourism and social multifunctional activities (hosting structures services, school farms, social farming practices, promotion of local products, etc.). In our country, the last period between the 2000 and 2010 censuses shows an

\footnotetext{
${ }^{3}$ It is worth to underline the European primacy in the world in protecting quality products through ad hoc legislation which regulates the attribution of quality certifications: Protected Designation of Origin (PDO), given to products whose entire "production, transformation and processing" phases take place "in a defined geographic area and characterized by a certified and recognized appraisal"; Protected Geographical Indication (PGI) attributed to productions whose link to a precise geographic area is present in at least one of the production phases: production, transformation or processing; Traditional Speciality Guaranteed (TSG) is independent from geographical localization because it only guarantees the traditional production method; Organic Product (BIO) is derived from agricultural practices exempt from the use of artificial agents, fertilizers and chemical pesticides.
}

accelerated evolution of regional agricultural systems with a sharp reduction of micro and small farms (from 0 to 2 ha.), going down from a total of 1.586 .777 to 824.652 with a $44 \%$ decrease. Also due to this phenomenon, it is recorded on the one hand a general decrease of TAA (Total Agricultural Area) up to $8 \%(17,081,099$ ha. in 2010 compared to $18,766,895.43$ in 2000), and on the other hand an increase in the average soil available per farm from 7.8 to 10.6 ha. In some remarkable cases, as illustrated in the graphics depicting them, the provincial agricultural systems overturned the supporting foundation of their economic productivity, shifting from medium to large-scale enterprises (figure 2)

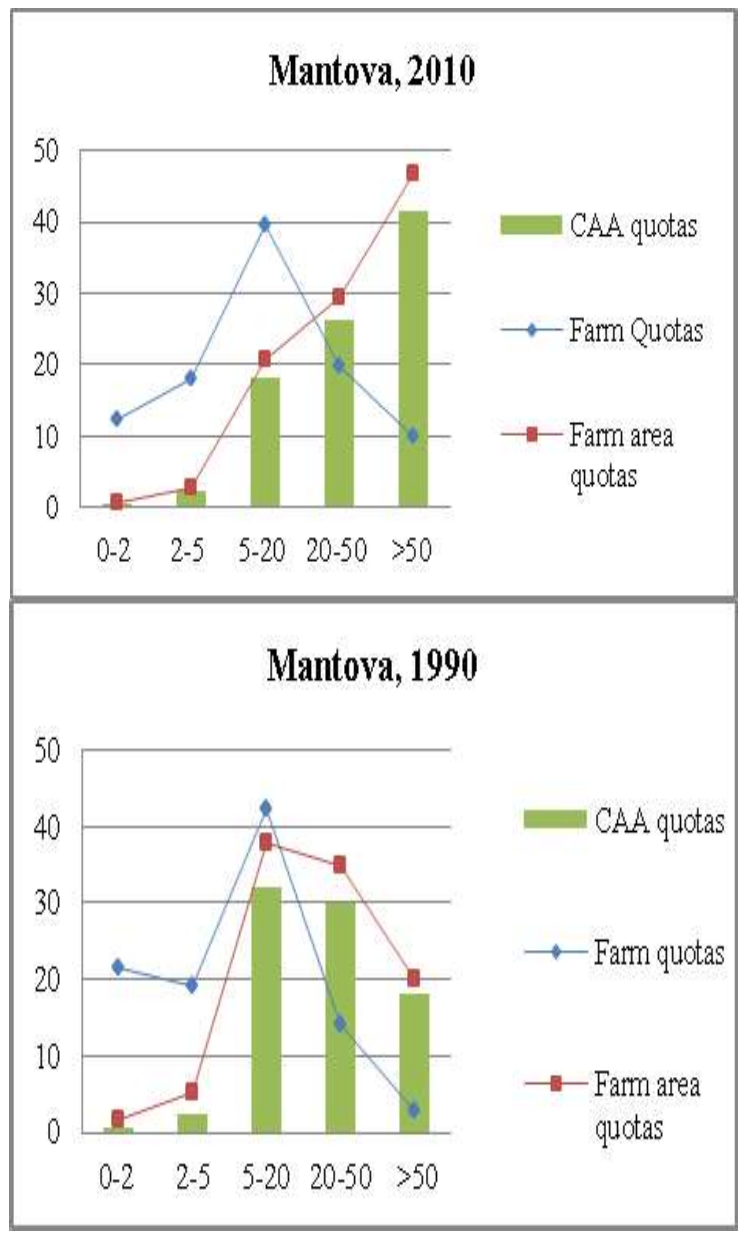

Figure 2. The transformation of production from one type of enterprises to another in the agricultural system of Mantova (1990 and 2010). Source: ISTAT data, our elaboration. 
In the $21^{\text {st }}$ century, new concerns and new demands have led therefore CAP to move from securing food availability to securing the production of quality products; those products more closely linked to environmental specificities and/or local traditions. The most adequate and immediate response to the new objectives comes from the farms of the Mediterranean basin countries $^{4}$, which had been for long marginalized by the European Union's incentives. Today even the concept of food security carries a twofold meaning: securing food supply and protection of food quality; both demands flowing into one main goal of optimizing population nutrition and guaranteeing availability to future generations. Each and every quality agrifood production is in fact the result of the commitment and knowledge of peasants handed down from generation to generation over the centuries to enhance the attributes of local rural areas, linking consumption to seasonality of products, and the collective traditions of agricultural operations. The protection of this heritage of production, processing and consumption traditions of typical local products brings the European Union, ahead of any other Organizations and Countries in the world, to enact relevant legislation that guarantees this heritage setting a model now also for nonEuropean countries interested in protecting their productions.

The latest CAP Reform (2014-2020), in an attempt to reconcile greening and food safety, stirs however ancient and unresolved conflicts between family farming and agro-industry systems, aggravated by new emerging social and energy problems such as the explosion of migratory flows and a sharp increase in the demand for bioenergy. The process of conversion to the territorial model and quality of products, which had finally channelled efforts towards recuperating food and agricultural knowledge, drawing on the environmental specificities and deeply rooted in local traditions, is today at risk because too many agricultural areas are dedicated to extensive annual monocultures. These are the very same

\footnotetext{
${ }^{4}$ The objectives that the laws to protect the primary sector want to achieve through the attribution of quality certifications are: 1) support to the diversification of production (biodiversity and food crafts) and to local development; 2) fighting food frauds, that become easier to identify; 3 ) educating consumers to the adoption of an adequate diet.
}

ones that were responsible for serious environmental damage (desertification and soil pollution), and they are paradoxically promoted to safeguard the environment with biomass cultivated for energy production purposes (Climate-Energy Package "20-20-20").

The definition of a new CAP also faces the heavy stall of European policies fuelled by the exponential wave of immigration of populations from the Southern Mediterranean countries toward Northern Europe. It is necessary and urgent to clarify some contradictory EU agricultural policy guidance: overcoming excessive exploitation of land can under no circumstances be pursued by reinstating cultivation models and methods proper of the plantation economy (monoculture and maximization of units' yields). These formulas, instead of rewarding local agriculture, placing emphasis on the work of productive units and the search for greater commitment on cultivations, are only adequate to respond to the demand for biodiesel and bioethanol. Biomass production, achieved by dedicating land to non-food crops, rather than responding to environmental goals is fuelling speculative interests which too often are unfortunately thriving on land grabbing in developing countries, exactly those countries which the so-called "economic refugees" whose lands have been grabbed are forced to flee. The effects of this last reform can be seen in the dynamism of rural areas, such as Italian ones, analysed by using the quali-quantitative GECOAGRI-LANDITALY Methodology, that underlines the complexity and the relationships between CAP and regional agricultural systems.

\section{THE EXTRAORDINARY EVOLUTION OF ITALIAN AGRICULTURAL SYSTEMS SEEN THROUGH THE GRAPHICS OF LOCAL AGRICULTURAL SYSTEMS (GECOAGRI-LANDITALY METHODOLOGY, FROM NOW ON REFERRED TO AS METHODOLOGY)}

The changes that have occurred in the last decades (1990-2010) in the Italian farms that were structurally stable in the 1980s and 1990s censuses emerged in the qualitative and quantitative analysis conducted with the survey methodology (registration SIAE No. 2007005663) [5 - 7] of the Interuniversity Research Group 
TẠP CHÍ PHÁT TRIỄN KHOA HỌC \& CÔNG NGHẸ: CHUYÊN SAN KHOA HỌC XÃ HộI VÀ NHÂN VĂN, TậP 1, SỐ 1, 2018

"GECOAGRI LANDITALY"5 . The methodology, presented to FAO on the occasion of the Second Steering Committee Meeting, Human Communities and natural environment in the agricultural areas (Rome, 7-9 June 2004) [8], envisages six investigation stages, each dedicated to the analysis of external factors, structural, economic, social, territorial and cultural ${ }^{6}$.

The methodological itinerary has been extensively tested and applied in Italy at different geographical levels, in Europe and in several nonEuropean countries, thus enabling to compare the new structural profiles of rural areas, both in different territorial contexts as well as under diachronic aspects. Fifteen monographs have been published, all dedicated to regional agricultural systems analyzed starting from the Methodology [9-24]. Furthermore, the publication of the Atlas of Italian Agriculture, which collects results at national level of Italian and European regional agricultural systems, which was translated into English and French, has facilitated diffusion of the Methodology beyond national boundaries [2].

For the purposes of this article, we will use only one of the characteristics of the methodology, the "structural" one, so defined because it investigates the farm through its constituent elements. The use of this specific element is justified because the resources for the article do not allow to analyse other elements. Notwithstanding this, the chosen element is still effective in representing in part,

\footnotetext{
${ }^{5}$ Acronym for Compared Geography of Agricultural Areas. The research group that involves several university professors, mostly geographers, promotes scientific activities for the valorisation of historical rural landscapes, for the promotion of local quality productions and for support to local development.

${ }^{6}$ External factors comprise the natural environment, agrarian policies and technological development. Structural factors comprise companies, TAA, UAA and CAA. Economic factors, on the other hand, evaluate the crop and production systems, GSP, and marketing the production. Social factors include land ownership, the demographic structure of the conductors, working days, labour and services used by the companies. Territorial factors include rural settlement, the shape of cultivated landscapes, land management and farming techniques, organization and functionality of the territory. Finally, the cultural features include cultural traditions and biodiversity, special products and quality of agrifood products, local habits, ceremonies, rites and rural songs. For a complete and detailed analysis of the GECOAGRI LANDITALY methodology in all its stages, including all characteristics of Italian agricultural systems, reference is made to the Thematic Atlas of Italian Agriculture, a milestone text for the study and comparison of the agricultural landscape organization [2] and to the two Grillotti's volumes specifically dedicated to the different phases of the methodology from a theoretical consideration.
}

also through the graphics, the objective of our research that in this stage is limited to assessing the dynamism of local farming systems.

The structural features of agricultural systems are composed of three parameters:

1) the percentage of the number of farms over the total territory divided according to size classes;

2) the percentage of the total enterprises' land area divided by the different size classes (TAA) over the total territory under investigation;

3 ) the percentage of the weighed enterprises' cultivated land area $(\mathrm{CAA})^{7}$.

The analysis of the graphical representation of these different parameters renders the "agricultural reality of a geopolitical space" placing the farm enterprise "as factual and real microcosm where the concerns of the rural world and of the relationship food-agricultureenvironment are reflected in their entirety" [25] at the centre of the research and analysis.

Furthermore, the analysis and the study of the structural features allows also to identify "the farm enterprises on which the primary sector is substantially founded [...] and to compare agricultural realities far away in space and time" [25].

This methodology facilitates to compare geographical realities at different levels (local, regional, national, global) and to evaluate outcomes over a period of time for the same territory (diachronic analysis). Well aware of the potential for research and analysis of the methodology, it was considered for this study some agricultural systems at the provincial level, thus favouring the choice of the impact and relevance of variations.

Based on data from the $6^{\text {th }}$ Agricultural Census provided by ISTAT, we have derived the graphics of the agricultural systems of Italian provinces (figures $3,4,5$ ), which clearly and unequivocally illustrate, a part from a few exceptions, that the farms with size class from 0 to 2 ha. that are characterized as 'micro', and those with size class

${ }^{7} \mathrm{CAA}$ includes all cultivated land (arable land, permanent crops, kitchen gardens, land with short rotation coppices connected to the holding, greenhouses, energy crops). Moreover, CAA values are calculated by comparing them to TAA values, so that the data describe the situation of the most productive farms, and we are provided with data regarding the relationship between cultivated land area and enterprises' total land area for every size class, showing the situations of weak, medium and high planting density [7-8]. 
from 2 to 5 ha. which are characterized as 'small' have registered a slow decline in favour of 'medium' (5-20 ha.) and 'large' (20-50 ha.) farms. This trend is evident, for example, in the agricultural system of the province of Naples (figure 3) where it is recorded not only a negative percentage change in number of farms compared with the graphics of agricultural systems in the 1990s [2], but also that the CAA values decrease in 'micro' farms in favour of the other farm size classes.

If in the ' 90 s of the past century the driving agricultural system in the province of Naples was that of 'micro' farms, in the census of 2010 this prevalence is lost in favour of 'small' and 'medium' farms. This trend concerns not only the provinces of Southern Italy, but also those in the centre. For example, in the province of Ancona (figure 4), where the dynamics of agricultural systems are the same: decreasing 'micro' farms in favour of 'medium-large' farms, while the share of CAA increases towards 'macro' farms, thus becoming the driving enterprises in the agricultural system of the province.

Moving towards Northern Italy, the trend of agricultural systems is confirmed. The province of Bologna (figure 5) registered a variation in the trend of the number of farms showing a decrease in 'micro' farms amounting to $-9 \%$ (1990-2010 variation), while the share of CAA decreased in medium-sized farms in favour of large ones that

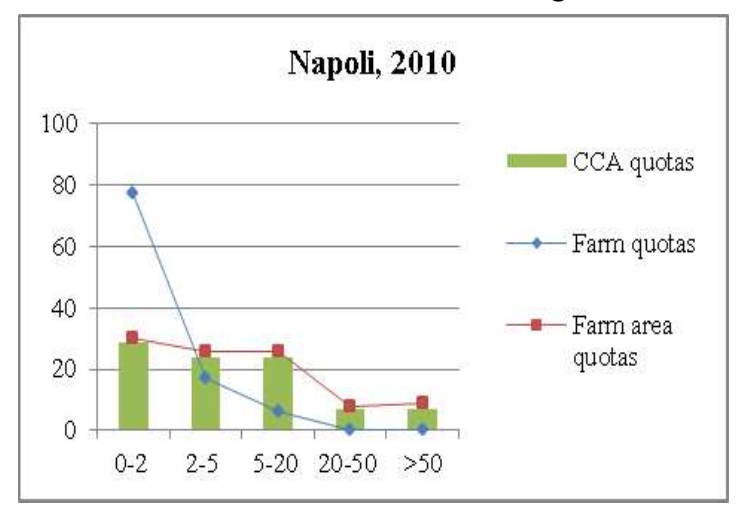

have become the dominant, driving agricultural system.

These data samples of the decline in farm quotas, confirmed in many other Italian provinces (Agrigento, L'Aquila, Arezzo, Viterbo, etc.), are very relevant because they reveal how the Italian agricultural landscape, historically and culturally characterized by the small agricultural reality that has guaranteed quality, tradition and also environmental protection and valorisation, is changing. The dynamism of micro and small businesses is a true icon of rural landscape and as such should be protected.

Family farming concealed behind the 'micro' and 'small' enterprises has given way to large and macro enterprises that have often englobed on behalf of speculative interests the realities of local farmers, thus undermining the fragile ecosystems and economic balance on top of cultural and social considerations. Of these imbalances, the methodology has, through the remaining stages, highlighted aporia and tendencies. This process in fact often goes hand-in-hand with several frequent cases of monocultural reconversions, which assign large land areas to the production of non-food, energy crops. It would be desirable for policymakers at various geographic levels consider agricultural systems as a privileged tool to trigger virtuous processes of valorisation and development [26].

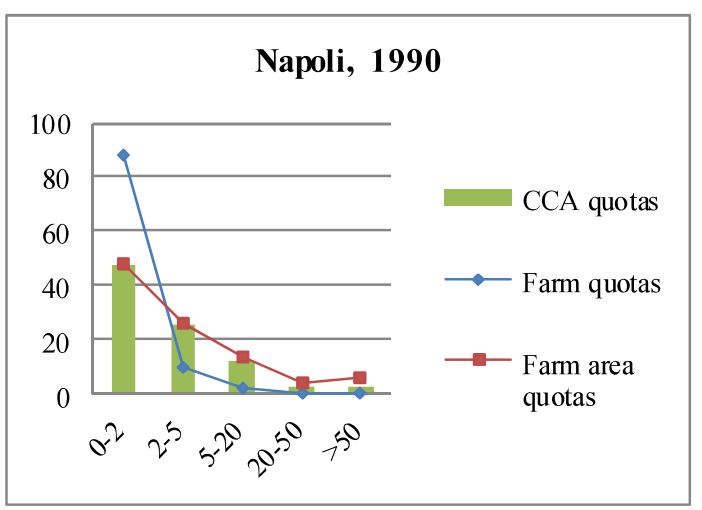

Figure 3. Agricultural system of the province of Naples (1990-2010).

Source: our elaboration based on ISTAT data, $6^{\text {th }}$ Agricultural Census, 2011 

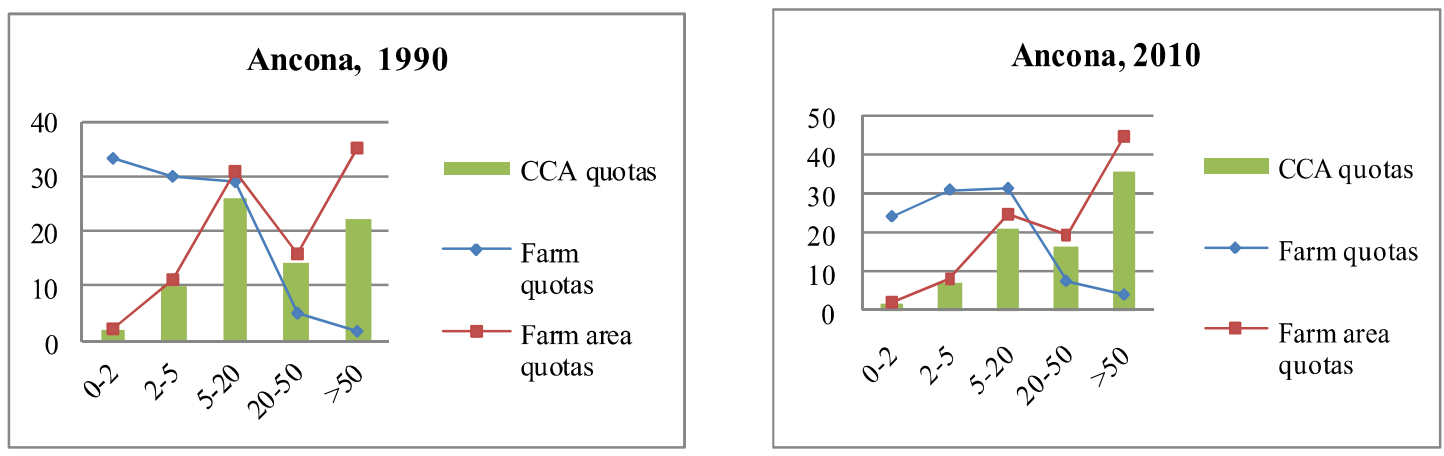

Figure 4. Agricultural system of the province of Ancona (1990-2010).

Source: our elaboration based on ISTAT data, $6^{\text {th }}$ Agricultural Census, 2011
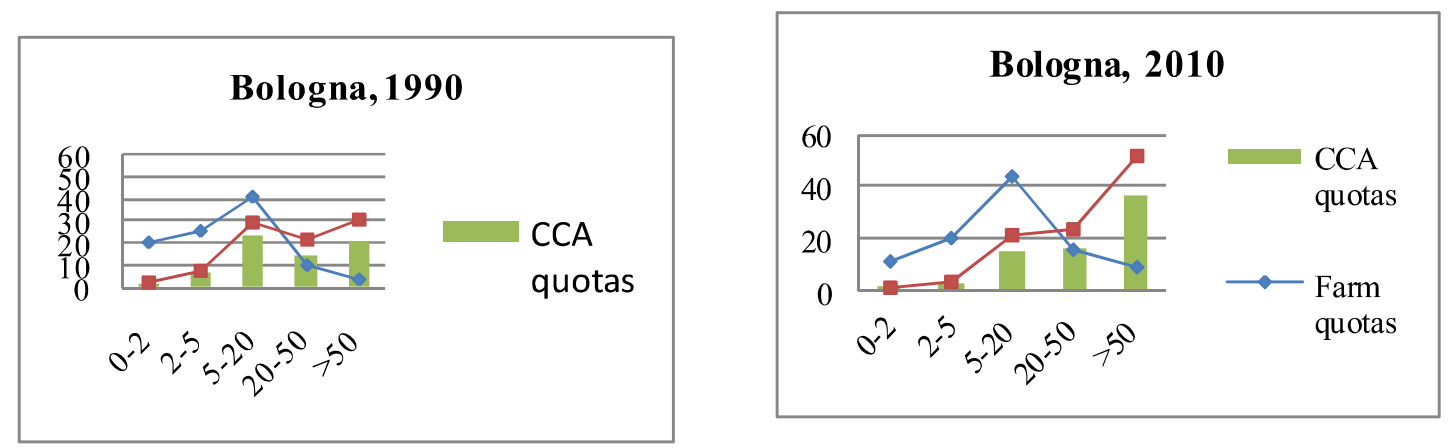

Figure 5. Agricultural system of the province of Bologna (1990-2010).

Source: our elaboration based on ISTAT data, $6^{\text {th }}$ Agricultural Census, 2011

\section{THE NEW CAP CHALLENGES BETWEEN LAND CONCENTRATION AND MONOCOLTURAL PRODUCTION}

The methodology has unequivocally and undeniably registered a change in the Italian regional agricultural systems that has revealed itself in the phenomenon of land concentration to which the monocultural production is closely linked. These trends brought to light by the methodology contribute to undermining the already fragile balance between agriculture and environment and compromise policies devised to enhance quality, specificity, conservation of local traditions for which the CAP has become a promoter during the last reform, and to which the rural areas of the Mediterranean countries, which have long been marginalized by the European Union's incentives, have immediately and adequately responded, and among which Italy represents a formidable example. The concept of quality is today closely associated with that of food security, which is no longer founded on the assurance of supply only, but also on the protection of food quality; policies converging on the foremost goal of optimizing population nourishment, and also ensuring availability to future generations. All - and each - quality agrifood production are in fact the result of the commitment and wisdom of peasants' traditions passed down the centuries to enhance the specificity of rural areas, always linking consumption to products' seasonality and the collective rites of agricultural operations. The protection of this heritage comprising production, processing and consumption modalities of typical local products, carried forward especially by small enterprises nowadays disappearing, has witnessed the European Union, well ahead of time compared to other organizations and countries in the world, set up a suitable legislative structure, now also looked upon by non-European countries interested in protecting their productions. Certainly, this is not enough to protect the product if at the same time the structural organization underpinning the production value chain represented by micro and small companies is not guaranteed. It is imperative and urgent to clarify some of these contradictory 
indications of the Union's agricultural policy: overcoming exploitation of land use can in no case be pursued by reconfirming cultivation models and methods typical of plantation economy (monoculture and maximization of unit yields). Such practices, instead of rewarding residential agriculture, the constant effort of productive units and the search for greater agricultural commitments, turn out to be adequate only to better respond to demands for biodiesel and bioethanol. Biomass production assigning rural areas to non-food crops rather than responding to agroecological goals on the other hand is fueling speculative interests, and the latter, in too many instances, are unfortunately achieved through land grabbing in developing countries, precisely those countries which migrants are forced to flee - the so called "economic refugees" - whose lands in reality were grabbed.

\section{REFERENCES}

[1]. Grillotti Di Giacomo M.G. La PAC e le trasformazioni dell'agricoltura italiana. Rapporto Annuale 2012 Società Geografica Italiana, Roma, pp. 51-55 (2012).

[2]. Grillotti Di Giacomo M. G. Atlante tematico dell'agricoltura italiana. Società Geografica Italiana, Roma (2000)

[3]. Grillotti Di Giacomo M.G., L'evoluzione della PAC. Rapporto Annuale 2012 Società Geografica Italiana Roma, pp. 49-51 (2012)

[4]. Grillotti Di Giacomo M.G, The relationship between Food-Agriculture-Environment compared with the new Common Agricultural Policy, geotema, 52, XX, pp. 8-17 (2016).

[5]. Grillotti Di Giacomo M.G., Metodologia GecoagriLanditaly. Metodologia di Indagine e Proposte Applicative per lo Sviluppo Integrato dei Sistemi Locali Rurali, Deposito SIAE, n. Repertorio 200700566310 (2007).

[6]. Grillotti Di Giacomo M.G., Moretti L. (eds) Atti del Convegno geografico internazionale "I valori dell'agricoltura nel tempo e nello spazio. Voll. I-II-III, Brigati, Genova (1998).

[7]. Grillotti Di Giacomo M. G. Una geografia per l'agricoltura. Lo sviluppo agricolo nello sviluppo territoriale italiano. Società Geografica Italiana, Roma (2000).

[8]. Grillotti Di Giacomo M. G. Una geografia per l'agricoltura. Metodologie di analisi e prospettive applicative per il mondo agrario e rurale italiano. Reda, Roma (1992).

[9]. Grillotti Di Giacomo M. G, Coordinamento scientifico, Prefazione metodologica e presentazione della regione, nei volumi della collana "Geografia dei sistemi agricoli italiani", Reda, Roma (1993-2000)

[10]. Morelli P., Umbria, Reda, Roma (1993).

[11]. Moretti L., Molise, Reda, Roma (1993).

[12]. Scarpelli L., Friuli-Venezia Giulia, Reda, Roma (1993).

[13]. Di Carlo P., Marche, Reda, Roma (1993).

[14]. Trischitta D., Calabria, Reda, Roma (1993).
[15]. Grosso N., Rollando A., Spotorno M., Liguria, Reda, Roma (1994).

[16]. Massimi G., Abruzzo, Reda, Roma (1994).

[17]. Moretti L., Campania, Reda, Roma (1995).

[18]. Falcioni P., Toscana, Reda, Roma (1995).

[19]. Scarpelli L., Veneto, Reda, Roma (1996).

[20]. Loi A., Zaccagnini M., Sardegna, Reda, Roma (1996).

[21]. Di Carlo P., Puglia, Reda, Roma (1996).

[22]. Morelli P. Basilicata, Reda, Roma (1996).

[23]. Moretti L., Lazio, S.G.I., Roma (1999).

[24]. Truffelli C., Emilia Romagna, S.G.I., Roma (2000).

[25]. Grillotti Di Giacomo M.G. Nutrire l'uomo, vestire il Pianeta Alimentazione-Agricoltura-Ambiente tra imperialismo e cosmopolitismo. Franco Angeli, Milano (2012).

[26]. De Felice P., Grillotti Di Giacomo M.G., Prometeo versus Demetra? Bioenergia, Agricoltura e Sostenibilità. Scienze e Ricerche, 13-15, pp. 23-32 (2015).

\section{Maria Gemma Grillotti Di Giacomo}

Professor, responsible for the problematics "Alimentation in the World" at the university Campus-BioMedico of Rome, Honary Member of the Geography Society of Paris, and was awarded with honours: The Grand Prix of Catographic 2001, of the 2011 Europe landscape award and the 2013 National Literary Prize; the writers with the green pen "Parco della Maiella". Coordinator of the Interuniversity Research Group "Comparative geography of European and extraEuropean agricultural areas", she developed the GECOAGRI-LANDITALY survey methodology, applied in Italy and abroad. She organized the Colloquium Quality Agriculture at FAO: Historical Heritage and Environmental Resources for an Integrated Development of Territories and the exhibition Ouer countryside's agri-cultures: quality of landscapes, values and tastes. Scientific consultant for the drafting of the D.L. n. 1600 of 25-05-2007 "Provisions for the Protection and Enhancement of the Rural Landscape", coordinated the 29th session of the CGI 2017 The current revolution of food models and the effects captured in the extraordinary dynamism of the Italian countryside. Among the approximately 170 publications, the ones that stand out are: the thematic Atlas of Italian agriculture and the thematic Atlas of Italian waters.

\section{Pierluig De Felice}

Doctor of research in historical geography. He was a research Fellow at the University of Cassino and Southern Lazio, studying the energy-territory relationship. He has collaborated with the ENEA research office, in the Ufficio Studi. Coordinated in 2017, the 29th session of the XXXII Italian Geographical Congress dedicated to the theme 
"The current revolution in dietary patterns and the effects captured in the extraordinary dynamism of the Italian countryside". He is adjunct professor at the Biomedical Campus and the University of Naples Federico II. He is the author of numerous publications on the topics of alimentation geography, historical cartography, toponymy, agricultural, medical and cultural geography. He is part of geographical associations such as the Italian Geographers Association (AGeI), the Geographical Society, the Italian Association of Geography Teachers, the Geographic Studies Society, the GECOAGRI LANDITALY research group of which he holds the position of secretary.

\title{
Những mâu thuẫn trong chính sách nông nghiệp chung của EU (CAP) trong quá trình chuyển đổi bất thường của hệ thống nông nghiệp Ý những năm gần đây
}

\author{
Pierluigi De Felice, Maria Gemma Grillotti Di Giacomo \\ Trường Đại học Campus Bio-Medico, Ý \\ Email tác giả liên hệ: p.defelice@unicampus.it
}

Ngày nhận bản thảo: 04/12/2017; ngày chấp nhận đăng: 27/01/2018; ngày đăng: 30/3/2018

Tóm tắt-Tác động của chính sách nông nghiệp chung châu Âu với nhiều quy định trái ngược nhau đối với quá trình chuyển biến mạnh mẽ của hệ thống nông nghiệp Ý những năm gần đây

Trong hai thập kỷ qua, hệ thống nông nghiệp Ý đã có sự chuyển biến cơ cấu mạnh mẽ, một phần là do tác động của Chính sách nông nghiệp chung châu Âu với nhiều quy định trái ngược nhau. Hai yếu tố quan trọng nhất đã tạo ra sự tiến hóa nhanh chóng ở vùng nông thôn chúng ta là: Sự công nhận và thu nhận bởi lĩnh vực cơ bản của các chức năng kinh tế, xã hội, môi trường và văn hoá mới, mặt khác sự quan tâm mới đến vẻ đẹp của các khu vực nông thôn, tầm quan trọng của sự sản xuất nông nghiệp với kỹ thuật bền vững và chất lượng của các nguồn cung cấp thực phẩm. Đối với tất cả những khía cạnh này, các nhà nghiên cứu và công chúng, hôm nay, nhận ra vai trò cơ bản của các người bảo lãnh cho chất lượng cuộc sống và sức khoẻ con người, động vật và môi trường. Đó là một nhận thức mới, phá võ sự chậm trễ truyền thống mà lĩnh vực chính đáp ứng với các hoạt động văn hoá, với một thời gian bất ngờ, đã chuyển thành các hình thức cụ thể, dễ thấy trong việc tổ chức lại công ty về đất đai. Áp dụng phương pháp định lượng và định tính của Nhóm nghiên cứu liên trường đại học GECOAGRI LANDITALY cho số liệu điều tra dân số mới nhất của ngành nông nghiệp trong năm 2010, đóng góp phản ánh sự phát triển gần đây của hệ thống nông nghiệp Ý để chứng minh kết quả cảnh quan và các vấn đề lãnh thổ.

Tù khóa-Hệ thống nông nghiệp địa phương, Chính sách Nông nghiệp Chung, GECOAGRI LANDITALY Phương pháp học 